\title{
Partial Purification of Peroxiredoxin-2 From Porcine Skeletal Muscle
}

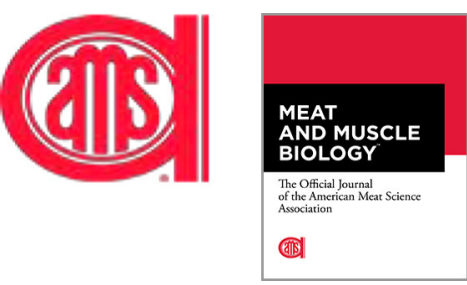

\author{
Logan G. Johnson, Edward M. Steadham, Elisabeth Huff-Lonergan, and Steven M. Lonergan*
}

Department of Animal Science, lowa State University, Ames, lowa 50011, USA

*Corresponding author. Email: slonerga@iastate.edu (Steven M. Lonergan)

\begin{abstract}
Fresh meat quality is adversely affected by protein oxidation. However, a fundamental understanding of the diverse factors that influence protein oxidation in postmortem muscle remains elusive. Peroxiredoxin-2 (Prdx2), an antioxidant protein, is more abundant in tough meat based on instrumental tenderness; however, the role of Prdx 2 in postmortem skeletal muscle is unknown. Therefore, the objective was to develop a method to purify Prdx 2 from the diaphragm, psoas major, and longissimus lumborum. Proteins soluble at low ionic strength were extracted, dialyzed, clarified, and loaded onto a Q-Sepharose anion exchange column equilibrated with TEM (pH 7.4). In all preparations, Prdx2 eluted between about 75 and $115 \mathrm{mM} \mathrm{NaCl}$. Immunoreactive fractions were dialyzed against TEM (pH 8.0), clarified, and loaded onto a DEAE-650S anion exchange column. In all preparations, Prdx2 eluted between approximately 55 and $75 \mathrm{mM} \mathrm{NaCl}$. Immunoreactive fractions were concentrated and loaded onto a Superose-12 size exclusion column. Prdx2 was detected between 14 and $16 \mathrm{~mL}$, and these fractions were concentrated and reduced with $0.5 \%$ 2-mercaptoethanol. A final pass over the Superose-12 column was conducted, and Prdx2 was detected in 2 peaks from 11-12 mL and 15-16 mL. Fractions 15-16 were pooled and retained for further experiments. The elution profile of Prdx 2 in all 3 muscles was similar. The identification of the primary protein was confirmed with liquid chromatography with tandem mass spectrometry. The purity of Prdx 2 off the final Superose- 12 column was approximately 33\%, 52\%, and 47\% pure in the diaphragm, psoas major, and longissimus lumborum, respectively. This is the first report of a method to partially purify Prdx 2 from skeletal muscle.
\end{abstract}

Key words: peroxiredoxin-2, porcine, anion exchange chromatography, size exclusion chromatography Meat and Muscle Biology 5(1): 29, 1-9 (2021)

doi: $10.22175 / \mathrm{mmb} .12408$

Submitted 28 March 2021

Accepted 6 May 2021

\section{Introduction}

Meat quality is affected by numerous biochemical events, including the rate and extent of protein oxidation. Protein oxidation in postmortem skeletal muscle can negatively affect meat tenderness development (Rowe et al., 2004a), water-holding capacity (Lund et al., 2007; Kim et al., 2010), and color (Mitacek et al., 2019) during extended postmortem aging. Fresh meat research often focuses on molecular changes caused by meat protein oxidation, including the quantification of carbonylation or other oxidative modifications (Estévez, 2011). However, there has been less emphasis on the role of endogenous proteins that may limit protein oxidation.
Peroxiredoxins are a family of thiol antioxidant proteins that exist to reduce reactive oxygen species, primarily hydrogen peroxide $\left(\mathrm{H}_{2} \mathrm{O}_{2}\right)$. There are 6 isoforms of peroxiredoxins expressed in mammalian tissue that vary in localization within the cell. Peroxiredoxin-2 (Prdx2) exists in the cytosol, whereas other isoforms, such as peroxiredoxin-3, reside primarily in mitochondria (Rhee and Woo, 2011). All peroxiredoxins have a conserved reactive cysteine $\left(C_{P}\right)$ found in a high-affinity peroxide binding site. In the peroxide binding site, a network of hydrogen bonds facilitates the interaction and stabilization between the peroxide substrate and renders the $C_{P}$ highly sensitive to oxidation (Rhee and Kil, 2017). A subfamily of peroxiredoxins-2-Cys peroxiredoxins, which 
includes Prdx2-has a resolving cysteine $\left(\mathrm{C}_{\mathrm{R}}\right)$. After oxidation of the $\mathrm{C}_{\mathrm{P}}$ to a sulfenic $\operatorname{acid}\left(\mathrm{C}_{\mathrm{P}}-\mathrm{SOH}\right)$, an intermolecular disulfide bond forms between the $C_{P}$ and the $\mathrm{C}_{\mathrm{R}}$ on an adjacent peroxiredoxin subunit. Alternatively, the $\mathrm{C}_{\mathrm{P}}-\mathrm{SOH}$ can be hyperoxidized to a sulfinic acid and subsequently a sulfonic acid. The oxidation of $\operatorname{Prdx} 2$ impacts the form of the protein, including dimeric and decameric forms of Prdx2.

In aged pork, total Prdx2 monomer was greater in abundance in pork chops classified as tough than in chops classified as tender by instrumental star probe (Carlson et al., 2017; Schulte et al., 2020). It is proposed that increased $\operatorname{Prdx} 2$ abundance indicates a response to oxidative environment. Oxidation is known to limit calpain activity and postmortem protein degradation (Rowe et al. 2004b; Carlin et al., 2006, Lametsch et al., 2008). The diversity in form and abundance of Prdx2 in skeletal muscle has also been compared among pigs with different phenotypes. Two bands of Prdx2 have been observed on a non-reducing gel (Patterson et al., 2021). The molecular weight difference between the two bands was proposed to be differences in known post-translational modifications, such as glutathionylation, s-nitrosylation, acetylation, or phosphorylation (Rhee and Woo, 2020). The specific alterations of the two bands have yet to be confirmed.

Peroxiredoxin-2 reacts rapidly with hydrogen peroxide similar to other more well-characterized antioxidant proteins, such as glutathione peroxidase and catalase. However, Prdx2 is more highly expressed than glutathione peroxidase and catalase, demonstrating the significance of peroxiredoxins as antioxidant proteins (Karplus, 2015). Compared with other isoforms of peroxiredoxins, $\operatorname{Prdx} 2$ abundance in aged meat is associated with proteolysis and meat tenderness. Therefore, it is necessary to define the various forms and oxidation states of $\operatorname{Prdx} 2$ in skeletal muscle to characterize better the mechanisms of how Prdx2 impacts meat quality development and skeletal muscle growth. We hypothesize that $\operatorname{Prdx} 2$ abundance increases perimortem in skeletal muscle in response to oxidative stress. The connection, if any, between the oxidation state of $\operatorname{Prdx} 2$ and postmortem meat quality development is unknown. The application of in vitro studies can assist in putting the observed difference in abundance and diversity of forms of $\operatorname{Prdx} 2$ in context. Therefore, the objective was to develop a method for the purification of Prdx 2 from porcine skeletal muscle so that a more detailed understanding of its function can be developed.

\section{Materials and Methods}

\section{Muscle sample collection}

Porcine skeletal muscle was obtained approximately $45 \mathrm{~min}$ postmortem from the Iowa State University Meat Laboratory. Diaphragm (DIA), psoas major (PM), and longissimus lumborum (LL) samples were immediately trimmed of visible connective and adipose tissue, finely minced, and immediately stored in a freezer at $-80^{\circ} \mathrm{C}$. Two $(n=2)$ separate purifications from all 3 muscles were conducted. The protein concentration of the elution fractions was measured with the Bradford dye-binding method (Bio-Rad, Hercules, CA).

\section{Detection of peroxiredoxin-2 using sodium dodecyl sulfate-polyacrylamide gel electrophoresis and immunoblotting}

Sodium dodecyl sulfate (SDS)-polyacrylamide gel electrophoresis and immunoblotting techniques, as described by Carlson et al. (2017) with modifications, were used to detect $\operatorname{Prdx} 2$ abundance in elution fractions. To detect Prdx2, $10 \mu \mathrm{L}$ from each elution fraction were combined with 0.83 vol of Wang's tracking dye ( $3 \mathrm{mM}$ ethylenediaminetetraacetic acid [EDTA], 3\% [wt/vol] SDS, 30\% [vol/vol] glycerol, $0.001 \%$ [wt/vol] pyronin $\mathrm{Y}$, and $30 \mathrm{mM}$ Tris-HCl [pH 8.0]) and 0.17 vol of 2-mercaptoethanol. Samples were heated for $15 \mathrm{~min}$ on a dry heat block at $50^{\circ} \mathrm{C}$.

Peroxiredoxin- 2 was detected using $15 \%$ polyacrylamide separating gels $(10 \mathrm{~cm}$ by $10 \mathrm{~cm}$; acrylamide: $\mathrm{N}$, N'-methylenebisacrylamide ratio: 100:1 [wt/wt], 0.1\% [wt/vol] SDS, $0.05 \%$ [vol/vol] N,N,N',N'-tetramethylethylenediamine, $0.05 \%$ [wt/vol] ammonium persulfate, and $0.5 \mathrm{M}$ Tris- $\mathrm{HCl}[\mathrm{pH} 8.8]$ ) overlayed with a 5\% stacking gel (acrylamide: N,N'-methylenebisacrylamide ratio: 100:1 [wt/wt], 0.1\% [wt/vol] SDS, $0.125 \% \quad[\mathrm{vol} / \mathrm{vol}] \quad \mathrm{N}, \mathrm{N}, \mathrm{N}$ ',N'-tetramethylethylenediamine, $0.075 \%$ [wt/vol] ammonium persulfate, and $0.125 \mathrm{M}$ Tris-HCl [pH 6.8]) with 10 lanes. Lane 1 of each gel was loaded with Precision Plus Protein All Blue molecular weight standards (Bio-Rad, Hercules, $\mathrm{CA}$ ). The remaining lanes were filled sequentially with the prepared gel samples from each fraction and run at a constant voltage of $120 \mathrm{~V}$ for about $360 \mathrm{~V} / \mathrm{h}$ with Hoefer 260 Mighty Small II units (Hoefer, Inc., Holliston, MA). The running buffer consisted of $25 \mathrm{mM}$ Tris, $192 \mathrm{mM}$ glycine, $2 \mathrm{mM}$ EDTA, and $0.1 \%[\mathrm{wt} / \mathrm{vol}] \mathrm{SDS}$. 
Following electrophoresis, fractionated proteins were transferred to polyvinylidene difluoride membranes, $0.2-\mu \mathrm{m}$ pore size $(88520$; Thermo Scientific, Rockford, IL) soaked in methanol for approximately $1 \mathrm{~min}$ before transfer. Gels were transferred onto membranes with TE-22 Mighty Small Transphor units (Hoefer, Inc.) at $90 \mathrm{~V}$ for $90 \mathrm{~min}$ at about $4^{\circ} \mathrm{C}$. The transfer buffer consisted of $25 \mathrm{mM}$ Tris, $192 \mathrm{mM}$ glycine, $2 \mathrm{mM}$ EDTA, and 15\% [vol/vol] methanol. After transfer, the membranes were incubated on a rocker in PBS-Tween (80 mM Na $2 \mathrm{HPO}_{4}, 20 \mathrm{mM} \mathrm{NaH}{ }_{2} \mathrm{PO}_{4}$, $100 \mathrm{mM} \mathrm{NaCl}$, and $0.1 \%$ [vol/vol] polyoxyethylene sorbitan monolaurate [Tween 20]) with 5\% nonfat dry milk to block for $1 \mathrm{~h}$ at room temperature. After blocking, the monoclonal rabbit anti-peroxiredoxin-2 antibody (ab109367; Abcam, Cambridge, UK) was diluted 1:40,000 in PBS-Tween and incubated with the membranes overnight (approximately $15 \mathrm{~h}$ ) at $4^{\circ} \mathrm{C}$. Following primary incubation, membranes were washed with PBS-Tween 3 times for $10 \mathrm{~min}$ each. Goat anti-rabbit-horseradish peroxidase antibody (31460; Thermo Scientific) was diluted $1: 10,000$ in PBSTween and incubated with the membranes for $1 \mathrm{~h}$ at room temperature. Membranes were then washed with PBS-Tween 3 times for $10 \mathrm{~min}$. Proteins were detected with a chemiluminescent detection kit (ECL Prime; GE Healthcare, Piscataway, NJ) and imaged with a ChemiImager 5500 (Alpha Innotech Corp., San Leandro, CA).

\section{Peroxiredoxin-2 purification}

The Prdx2 purification methods were partially developed based on descriptions to purify $\operatorname{Prdx} 2$ from erythrocytes (Lim et al., 1994; Bayer, 2015). Samples from each muscle $(20 \mathrm{~g})$ were homogenized separately in $3 \mathrm{vol}(\mathrm{wt} / \mathrm{vol})$ of ice-cold $\left(4^{\circ} \mathrm{C}\right)$, lowionic-strength buffer (50 mM Tris- $\mathrm{HCl}[\mathrm{pH} 8.5]$ and 1 mM EDTA) using a Polytron PT 3100 (Kinematica, Lucerne, Switzerland) in two, 10-s bursts. The homogenates were clarified at $10,000 \times g$ for $30 \mathrm{~min}$ at $4{ }^{\circ} \mathrm{C}$. The supernatant was filtered through cheesecloth and dialyzed in Spectra/Por 4 dialysis tubing with a molecular weight cutoff of $12-14 \mathrm{kDa}$ (Spectrum, Rancho Dominguez, CA) against 40 vol (7 L) of $40 \mathrm{mM}$ Tris-HCl (pH 7.4), $1 \mathrm{mM}$ EDTA, and $0.1 \%$ 2-mercaptoethanol (TEM [pH 7.4]) overnight (approximately $15 \mathrm{~h}$ ) at $4^{\circ} \mathrm{C}$. Dialyzed extracts were clarified by centrifugation at $10,000 \times g$ for $30 \mathrm{~min}$ at $4^{\circ} \mathrm{C}$ and filtered through cheesecloth. Peroxiredoxin-2 was detected in all 3 tissues using western blots (Figure 1).

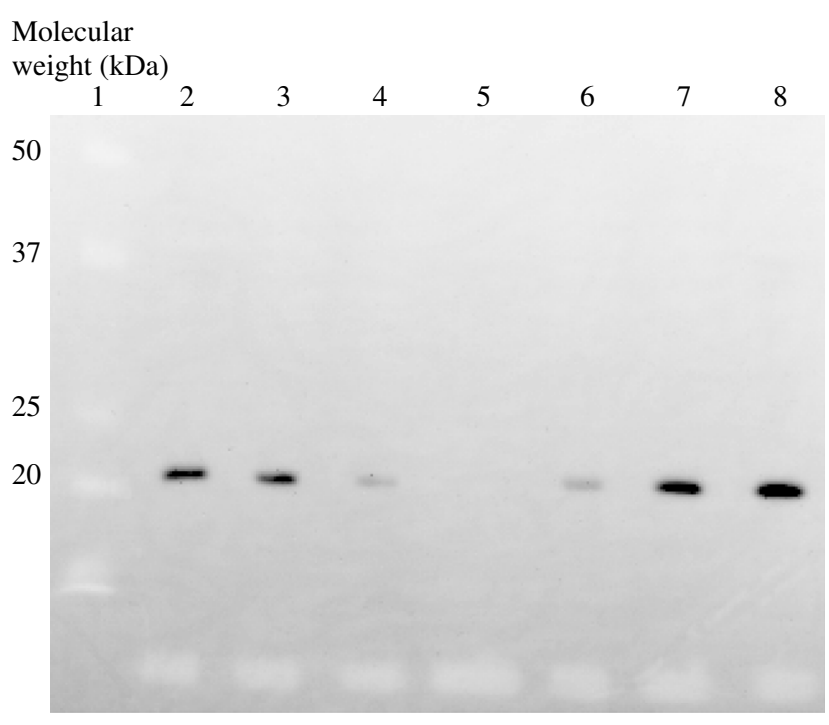

Figure 1. Representative western blot comparing the abundance of peroxiredoxin-2 (Prdx2) from dialyzed sarcoplasmic extracts of diaphragm, psoas major, and longissimus lumborum from one purification. Lane 1: Molecular weight standard; Lanes 2 and 8: Diaphragm; Lanes 3 and 7: Psoas major; Lanes 4 and 6: Longissimus lumborum; and Lane 5: Blank. Lanes 2-4 were loaded with $40 \mu \mathrm{g}$ of total protein, and Lanes 6-8 were loaded with $60 \mu \mathrm{g}$ of total protein.

Clarified dialysates were loaded onto separate $20 \mathrm{~mL}$ Q-Sepharose Fast Flow anion exchange columns (Amersham Biosciences, Piscataway, NJ) equilibrated with TEM ( $\mathrm{pH}$ 7.4) with an ÄKTAprime plus liquid chromatography system (GE Healthcare Bio-Sciences Corp., Piscataway, NJ). Loaded columns were washed with $200 \mathrm{~mL}$ of TEM ( $\mathrm{pH}$ 7.4). Proteins were eluted with a linear gradient of 75 to $500 \mathrm{mM} \mathrm{NaCl}$ in TEM (pH 7.4) over $400 \mathrm{~mL}$ (Figure 2A).

Immunoreactive fractions were pooled and dialyzed against $40 \mathrm{vol}(6 \mathrm{~L})$ of $40 \mathrm{mM}$ Tris- $\mathrm{HCl}$ (pH 8.0), $1 \mathrm{mM}$ EDTA, and 0.1\% 2-mercaptoethanol (TEM [pH 8.0]) overnight at $4^{\circ} \mathrm{C}$. Dialysates were clarified by centrifugation at $10,000 \times g$ for $30 \mathrm{~min}$ at $4^{\circ} \mathrm{C}$ and filtered through cheesecloth. Clarified dialysates were loaded separately on a $20 \mathrm{~mL}$ Toyopearl DEAE-650S anion exchange column (Supelco, Bellefonte, PA) equilibrated with TEM ( $\mathrm{pH}$ 8.0). Each column was washed with $200 \mathrm{~mL}$ of TEM (pH 8.0), and proteins were eluted with a linear gradient of 0 to $500 \mathrm{mM} \mathrm{NaCl}$ in TEM (pH 8.0) over $300 \mathrm{~mL}$ (Figure 3A).

Immunoreactive fractions were pooled and concentrated with an Amicon Ultra centrifugal filter (Merck Millipore, Carrigtwohill, Ireland) with a molecular weight cutoff of $10-\mathrm{kDa}$ at $3,000 \times g$ and $4^{\circ} \mathrm{C}$. Buffers for gel filtration were filtered through a bottle-top vacuum filter $(0.22-\mu \mathrm{m}$ pore size; Thermo Scientific). A Superose-12 10/300 GL size exclusion 


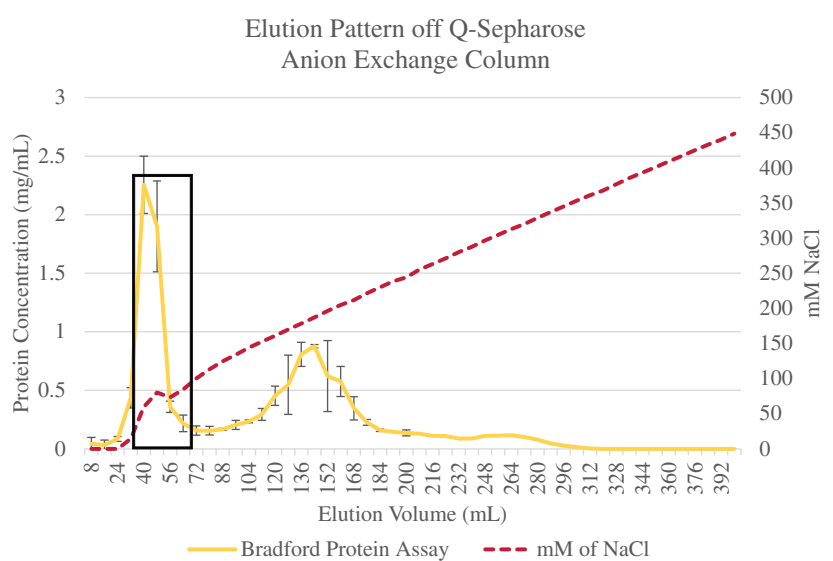

(A)

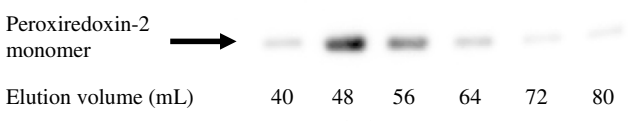

(B)

Figure 2. Representative (A) elution program and protein concentration of the elution fractions off the Q-Sepharose anion exchange column and (B) western blot of elution fractions off the Q-Sepharose column for peroxiredoxin-2 (Prdx2). The elution patterns and western blots of Prdx2 were similar, regardless of muscle; thus, only the diaphragm data are presented. Protein concentration is reported as an average \pm standard deviation from two different preparations. The outlined region represents the immunoreactive fractions for Prdx2.

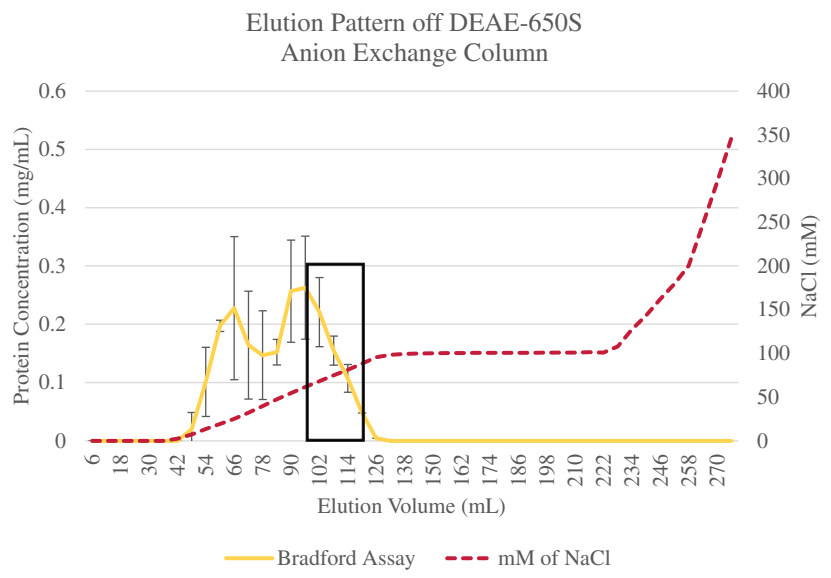

(A)

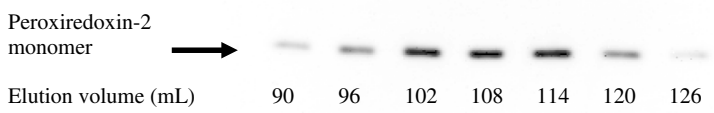

(B)

Figure 3. Representative (A) elution program and protein concentration of elution fractions off the DEAE-650S anion exchange column and (B) western blot of elution fractions off the DEAE-650S column for peroxiredoxin-2 (Prdx2). The elution patterns and western blots of Prdx2 were similar, regardless of muscle; thus, only the diaphragm data are presented. Protein concentration is reported as an average \pm standard deviation from two different preparations. The outlined region represents the immunoreactive fractions for $\operatorname{Prdx} 2$. column (GE Healthcare Bio-Sciences Corp.) was equilibrated with TEM (pH 7.4) with $150 \mathrm{mM} \mathrm{NaCl}$. The concentrated proteins (about $1 \mathrm{~mL}, 2 \mathrm{mg}$ protein) were loaded onto the Superose- 12 column and fractionated with TEM (pH 7.4) with $150 \mathrm{mM} \mathrm{NaCl}$ at a rate of $0.2 \mathrm{~mL}$ per min in $1 \mathrm{~mL}$ fractions for a total of $30 \mathrm{~mL}$ (Figure 4A).

Elution fractions 14-16 were pooled and concentrated with an Amicon Ultra centrifugal filter (Merck Millipore) with a molecular weight cutoff of $10-\mathrm{kDa}$ at $3,000 \times g$ at $4^{\circ} \mathrm{C}$ until concentrated to a volume of less than $1 \mathrm{~mL} .0 .5 \%$ (vol/vol) 2-mercaptoethanol was added directly to the concentrated protein sample on ice for $3 \mathrm{~h}$ to elicit reducing conditions. The concentrated protein sample was loaded onto a Superose12 size exclusion column equilibrated with filtered $40 \mathrm{mM}$ Tris- $\mathrm{HCl}$ (pH 7.4), $1 \mathrm{mM}$ EDTA, and $0.5 \%$ 2-mercaptoethanol with $150 \mathrm{mM} \mathrm{NaCl}$ and fractionated with the same buffer at $0.2 \mathrm{~mL}$ per min in $1 \mathrm{~mL}$ fractions for a total of $30 \mathrm{~mL}$ (Figure $5 \mathrm{~A}$ ).

\section{Evaluation of purification}

Protein $(5 \mu \mathrm{g})$ from pooled fractions after each column chromatography step was used to visualize the

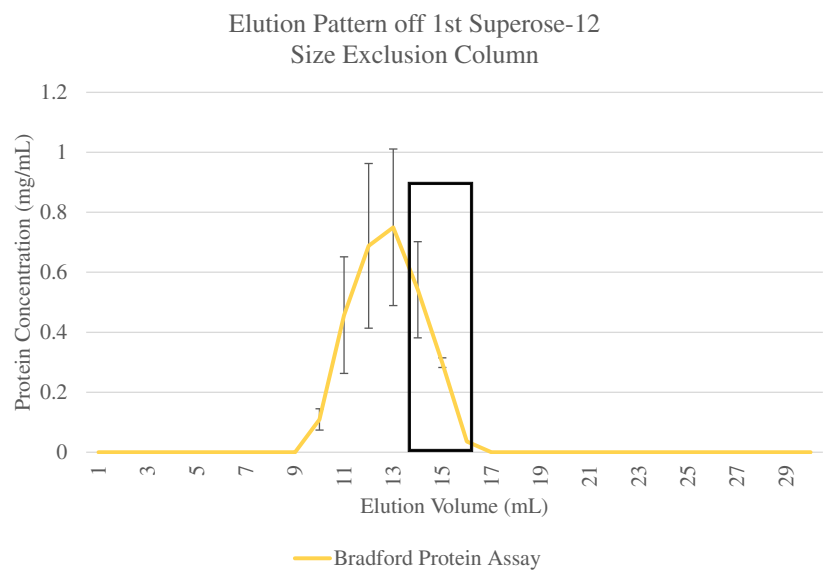

(A)

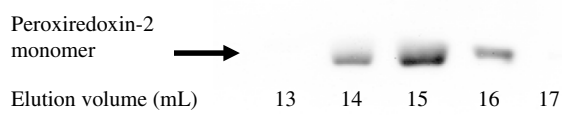

(B)

Figure 4. Representative (A) protein concentration of elution fractions off the Superose-12 size exclusion column and (B) western blot of elution fractions off the Superose-12 column for peroxiredoxin-2 (Prdx2). The elution patterns and western blots of Prdx2 were similar, regardless of muscle; thus, only the diaphragm data are presented. Protein concentration is reported as an average \pm standard deviation from two different preparations. The outlined region represents the immunoreactive fractions for $\operatorname{Prdx} 2$. 


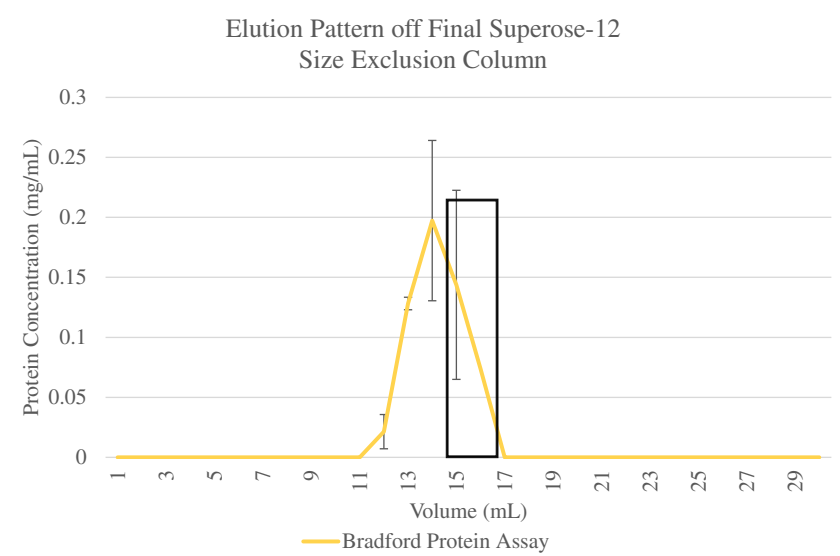

(A)

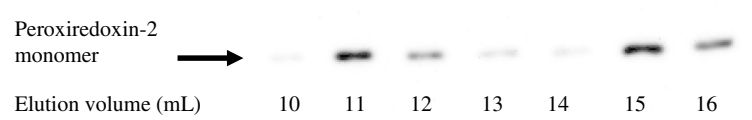

(B)

Figure 5. Representative (A) elution program and protein concentration off the Superose-12 size exclusion column and (B) western blot of elution fractions of the Superose-12 column for peroxiredoxin-2 (Prdx2). The elution patterns and western blots of $\operatorname{Prdx} 2$ were similar, regardless of muscle; thus, only the diaphragm data are presented. Protein concentration is reported as an average \pm standard deviation from two different preparations. The outlined region represents the immunoreactive fractions for Prdx2.

protein profile and partial purification of Prdx2 (Figure 6). Protein $(5 \mu \mathrm{g})$ from the final Superose-12 size exclusion column of each muscle was precipitated by the addition of 4 vol of ice-cold methanol and subsequently incubated at $-80^{\circ} \mathrm{C}$ for $30 \mathrm{~min}$. Proteins were precipitated by centrifugation at $21,694 \times g$ for $30 \mathrm{~min}$ at $4^{\circ} \mathrm{C}$. Precipitated proteins and all other samples were reconstituted with $10 \mu \mathrm{L}$ of a solution containing 0.83 vol of Wang's tracking and 0.17 vol of 2-mercaptoethanol. Samples were heated for $15 \mathrm{~min}$ on a dry heat block at approximately $50^{\circ} \mathrm{C}$. The prepared gel samples were loaded into $15 \%$ polyacrylamide separating gels overlayed with a 5\% stacking gel with ingredients filtered through a bottle-top vacuum filter $(0.22-\mu \mathrm{m}$ pore size; Thermo Scientific), and the gels were run at a constant voltage of $120 \mathrm{~V}$ for $360 \mathrm{~V} / \mathrm{h}$ on Hoefer 260 Mighty Small II units. Following electrophoresis, gels were stained with filtered Colloidal Coomassie Blue stain (17\% [wt/vol] ammonium sulfate, $33 \%$ [vol $/ \mathrm{vol}$ ] methanol, $0.03 \%$ [vol/vol] phosphoric acid, and $0.1 \%$ [wt/vol] Coomassie G-250). Gels were destained with filtered double-distilled water, changed 2 times. Gels were imaged with a Chemilmager 5500 (Alpha Innotech Corp.) and analyzed with Alpha Ease FC software (version 3.03, Alpha Innotech Corp.). The pooled samples' purity was determined by a ratio of the $22-\mathrm{kDa}$ band's densitometry compared with the sum of the total densitometry bands within a lane.

The 22-kDa band, outlined in Figure 6, was excised and submitted to the Iowa State University Protein Facility to determine the protein identity. The sample was digested with trypsin using an
(A)

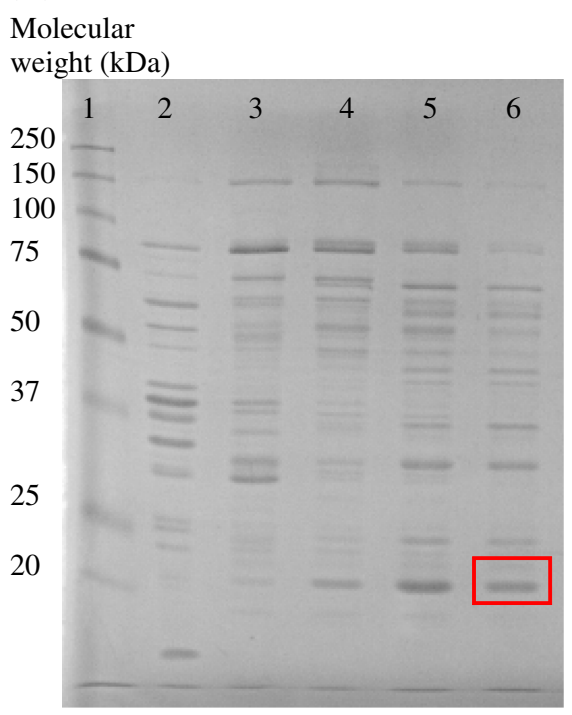

(B)

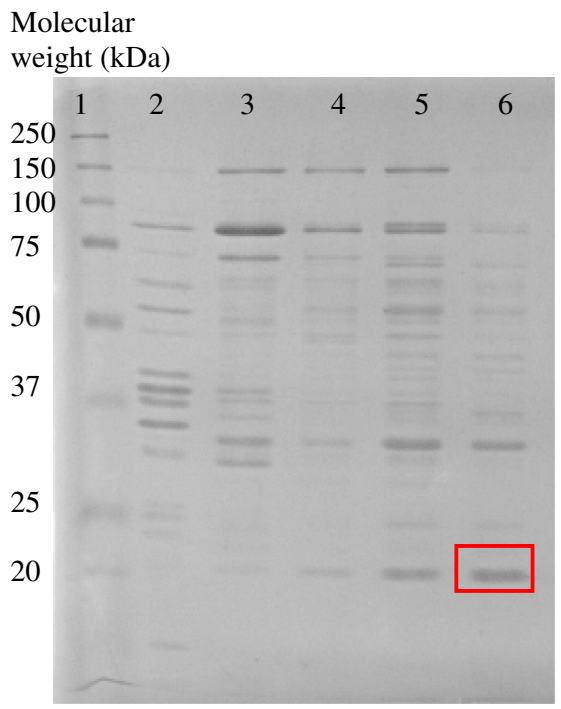

(C)

Molecular weight $(\mathrm{kDa})$

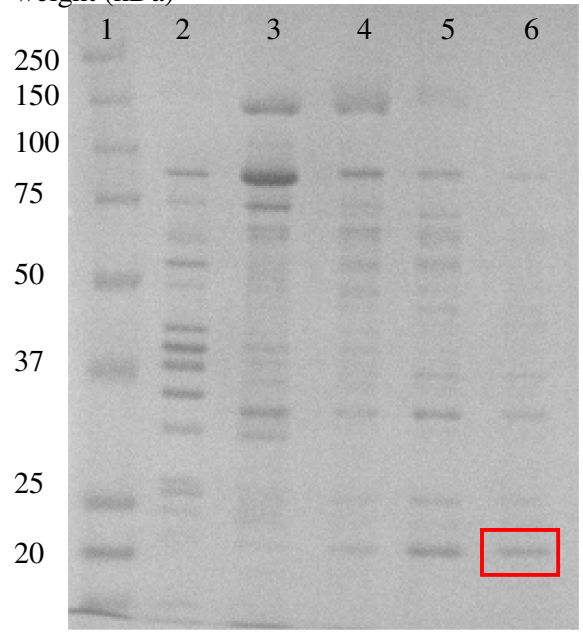

Figure 6. Colloidal Coomassie-stained $15 \%$ sodium dodecyl sulfate-polyacrylamide gels to demonstrate the protein profile and partial purification of peroxiredoxin-2 (Prdx2) from the diaphragm (A), psoas major (B), and longissimus lumborum (C). Lane 1: Molecular weight standard; Lane 2: Dialyzed sarcoplasmic protein extract; Lane 3: Pooled and dialyzed elution off Q-Sepharose anion exchange column; Lane 4: Pooled elution off DEAE-650S anion exchange column; Lane 5: Pooled elution off first Superose-12 size exclusion column; and Lane 6: Pooled elution off final Superose-12 size exclusion column. The outlined region represents the band excised for protein identification. 
Investigator ProGest (Genomic Solutions, Inc., Chelmsford, MA) automated digestor. The peptides were separated by reverse-phase liquid chromatography using a C18 column. The peptides were eluted and introduced to the Q Exactive Hybrid Quadrupole-Orbitrap Mass Spectrometer (Thermo Scientific) and analyzed with tandem mass spectrometry. The raw spectra were analyzed with Proteome Discoverer software (version 2.4.0.305; Thermo Scientific). The fragmentation pattern of identified peptides was compared with Sequest HT and Mascot databases against Sus scrofa to identify proteins.

\section{Results and Discussion}

Peroxiredoxin-2 is a highly reactive thiol antioxidant protein that reacts primarily with hydrogen peroxide. In skeletal muscle, various oxidation states of $\operatorname{Prdx} 2$, including dimeric, hyperoxidized, and decameric, have been observed. The form and abundance of Prdx2 from skeletal muscle of pigs of differing health status and residual feed intake vary (Patterson et al., 2021). In aged pork classified as tough, total monomeric Prdx 2 was greater than pork classified as tender (Carlson et al., 2017; Schulte et al., 2020). The variation in oxidation state and abundance of $\operatorname{Prdx} 2$ is different based on phenotype and instrumental meat tenderness classification. However, the role of $\operatorname{Prdx} 2$ in postmortem skeletal muscle is unknown. It is crucial to understand the role of $\operatorname{Prdx} 2$ to characterize the changes of Prdx 2 oxidation state and abundance in order to relate better those changes to meat quality and oxidative stress responses in postmortem skeletal muscle.

Three muscles were utilized because of their muscle fiber type differences, in that the PM relies on more oxidative metabolism than the other two. In contrast, the LL depends more on glycolytic metabolism of energy (Melody et al., 2004). The DIA contains a more heterogeneous mixture of muscle fiber types but relies primarily on oxidative metabolism (Toniolo et al., 2004). As visualized in Figure 1, Prdx 2 abundance was different between the sarcoplasmic extract, where the DIA and PM had a greater abundance of Prdx2 than the LL. Oxidative metabolism occurs in the mitochondria, where a significant amount of reactive oxygen species, such as hydrogen peroxide, are known to be produced (Brand, 2016). Skeletal muscles that rely on oxidative metabolism have a greater abundance of mitochondria than skeletal muscles that rely on glycolytic metabolism (Glancy and Balaban, 2011).
Therefore, oxidative skeletal muscles have the potential to produce a greater amount of hydrogen peroxide. Presumably as a response to the generation of hydrogen peroxide, the more oxidative muscles-such as the DIA and PM-maintain a greater abundance of Prdx2 to mitigate oxidative damage.

Peroxiredoxin-2 has an isoelectric point of about 5.6 (Matte et al., 2013). When dialyzed against the column buffer at $\mathrm{pH} 7.4, \operatorname{Prdx} 2$ would have a net negative charge and bind to an anion exchange column. In preparations from all muscles, Prdx2 eluted from the Q-Sepharose anion exchange column at approximately 75 to $115 \mathrm{mM} \mathrm{NaCl}$, as confirmed by immunoblot analysis (Figure 2B). Proteins that did not bind to the Q-Sepharose column were removed from the protein pool through a column washing step. Figure 2A shows the protein elution pattern off the Q-Sepharose column with 2 major protein peaks. The first protein peak eluted immediately at $75 \mathrm{mM} \mathrm{NaCl}$, and a second protein peak eluted between approximately 125 and $225 \mathrm{mM} \mathrm{NaCl}$ (Figure 2A). The protein that eluted between 125 and $225 \mathrm{mM} \mathrm{NaCl}$ contained no immunoreactive Prdx2; thus, the Q-Sepharose anion exchange column achieved a desired fractionation of proteins.

In preparations from all muscles, $\operatorname{Prdx} 2$ eluted at approximately 55 to $75 \mathrm{mM} \mathrm{NaCl}$ off the DEAE$650 \mathrm{~S}$ anion exchange column, as confirmed by immunoblot analysis (Figure 3B). Bayer (2015) and Lim et al. (1994) utilized a DEAE-Sepharose anion exchange column to purify Prdx 2 from erythrocytes. They report the elution of Prdx2 starting at about $160 \mathrm{mM} \mathrm{NaCl}$ and about $150-250 \mathrm{KCl}$, respectively. When using the DEAE-650S column at $\mathrm{pH}$ 7.4, Prdx2 eluted immediately at the start of the elution buffer up to $40 \mathrm{mM} \mathrm{NaCl}$ (data not shown). The $\mathrm{pH}$ was raised from 7.4 to 8.0 to achieve stronger protein binding and more efficient fractionation. By changing the $\mathrm{pH}$ from 7.4 to 8.0, a greater separation of proteins was achieved as no immunoreactive Prdx 2 eluted between 0 and $55 \mathrm{mM}$ $\mathrm{NaCl}$, yet other proteins were detected in those respective fractions (Figure 3A). Therefore, the DEAE-650S anion exchange column was a partial purification step for Prdx2.

Size exclusion chromatography was employed to fractionate proteins by molecular weight. Peroxiredoxin-2 monomers have a molecular weight of approximately $22-\mathrm{kDa}$ and would elute later in the elution compared with higher-molecular-weight proteins. Peroxiredoxin-2 was detected between 14 and $16 \mathrm{~mL}$ off the Superose-12 size exclusion column using immunoblot analysis (Figure 4B). Between 10 and 
$13 \mathrm{~mL}$, protein was detected, yet no immunoreactive Prdx2 was observed (Figure 4A).

After the first Superose-12 size exclusion column, $0.5 \%$ (vol/vol) 2-mercaptoethanol was added directly to the pooled and concentrated Prdx2 sample. This was necessary to maintain a greater proportion of $\operatorname{Prdx} 2$ in a monomeric state. Peroxiredoxin- 2 eluted in 2 separate peaks from fractions $11-12$ and $15-16$, as confirmed by immunoblot analysis (Figure 5B). It is hypothesized that the high abundance of $\operatorname{Prdx} 2$ and its reactive cysteines results in intermolecular disulfide bonds between Prdx 2 monomers during concentration. When dimerized, Prdx 2 has a higher molecular weight of approximately 44-kDa and would elute earlier than the $22-\mathrm{kDa}$ monomer. Only fractions 15 and 16 were pooled and saved for further analysis.

The 22-kDa band, outlined in Figure 6, comprised approximately $33 \%, 52 \%$, and $47 \%$ of the total densitometry within the pooled elution off the final Superose-12 size exclusion column for the DIA, PM, and LL, respectively. Liquid chromatography with tandem mass spectrometry analysis of the excised bands demonstrates that most of the band comprises Prdx2 (Table 1) regardless of muscle tissue. The Prdx2 preparation from the PM was specifically and uniquely assigned to Prxd2 Accession Number F1SDX9 (a 198 amino acid protein with a predicted molecular weight of 22,254 Da and an isoelectric point of 5.6).

Table 1. A summary of individual peptides of peroxiredoxin-2 identified from liquid chromatography with tandem mass spectrometry analysis.

\begin{tabular}{|c|c|c|c|c|c|c|}
\hline $\begin{array}{l}\text { Muscle } \\
\text { Tissue }\end{array}$ & $\begin{array}{c}\text { Protein } \\
\text { Identification }\end{array}$ & Species & $\begin{array}{c}\text { Accession } \\
\text { Number }\end{array}$ & $\begin{array}{c}\text { Coverage } \\
(\%)\end{array}$ & Identified Peptides & $\mathrm{PSM}^{1}$ \\
\hline Diaphragm & Peroxiredoxin-2 & $\begin{array}{c}\text { Sus } \\
\text { scrofa }\end{array}$ & F1SDX9 & 49 & $\begin{array}{l}\text { EDEGIAYR } \\
\text { EGGLGPLKIPLLADVTR } \\
\text { GLFIDGK } \\
\text { KEGGLGPLK } \\
\text { IPLLADVTR } \\
\text { LSDYKGK } \\
\text { LVQAFQYTDEHGEVCPAGWKPGSDTIKPNVDDSK } \\
\text { NLSLDYGVLK } \\
\text { NLSLDYGVLKEDEGIAYR } \\
\text { QITVNDLPVGR }\end{array}$ & $\begin{array}{c}938 / \\
2,210\end{array}$ \\
\hline Psoas Major & Peroxiredoxin-2 & $\begin{array}{c}\text { Sus } \\
\text { scrofa }\end{array}$ & F1SDX9 & 82 & $\begin{array}{l}\text { AEEFHQLGCEVLGVSVDSQFTHLAWINTPR } \\
\text { EDEGIAYR } \\
\text { EGGLGPLKIPLLADVTR } \\
\text { GLFIIDGKGVLR } \\
\text { GVLRQITVNDLPVGR } \\
\text { KEGGLGPLK } \\
\text { KEGGLGPLKIPLLADVTR } \\
\text { IPLLADVTR } \\
\text { LVQAFQYTDEHGEVCPAGWKPGSDTIKPNVDDSK } \\
\text { LVQAFQYTDEHGEVCPAGWKPGSDTIKPNVDDSKEYFSK } \\
\text { LVQAFQYTDEHGEVCPAGWKPGSDTIKPNVDDSKEYFSKHN } \\
\text { NLSLDYGVLK } \\
\text { NLSLDYGVLKEDEGIAYR } \\
\text { QITVNDLPVGR } \\
\text { QITVNDLPVGRSVDEALR } \\
\text { YLVLFFYPLDFTFVCPTEIIAFSDR }\end{array}$ & $\begin{array}{l}1,354 / \\
2,713\end{array}$ \\
\hline $\begin{array}{l}\text { Longissimus } \\
\text { Lumborum }\end{array}$ & Peroxiredoxin-2 & $\begin{array}{c}\text { Sus } \\
\text { scrofa }\end{array}$ & F1SDX9 & 51 & $\begin{array}{l}\text { EDEGIAYR } \\
\text { EGGLGPLKIPLLADVTR } \\
\text { GLFIIDGK } \\
\text { GLFIIDGKGVLR } \\
\text { KEGGLGPLK } \\
\text { IPLLADVTR } \\
\text { LSDYKGK } \\
\text { LVQAFQYTDEHGEVCPAGWKPGSDTIKPNVDDSK } \\
\text { NLSLDYGVLK } \\
\text { NLSLDYGVLKEDEGIAYR } \\
\text { QITVNDLPVGR }\end{array}$ & $\begin{array}{l}1,145 / \\
2,551\end{array}$ \\
\hline
\end{tabular}

${ }^{1}$ PSM: Peptide-spectrum matches, the total number of identified peptide sequences, including redundant peptides. Data reported as PSM of peroxiredoxin-2/ total PSM identified. 
Table 2. A comparison of the densitometry of the $22-\mathrm{kDa}$ band to the total densitometry within each lane, the calculated fold change after each column purification step, and the total protein content from one preparation.

\begin{tabular}{|c|c|c|c|c|c|c|c|c|c|c|c|c|c|c|c|}
\hline \multirow[b]{2}{*}{ Muscle Tissue } & \multicolumn{3}{|c|}{$\begin{array}{c}\text { Sarcoplasmic } \\
\text { Extract }\end{array}$} & \multicolumn{3}{|c|}{ Q-Sepharose } & \multicolumn{3}{|c|}{ DEAE-650S } & \multicolumn{3}{|c|}{ First Superose-12 } & \multicolumn{3}{|c|}{ Final Superose-12 } \\
\hline & $\% 1$ & $\mathrm{TP}^{2}$ & $\overline{\mathrm{FC}^{3}}$ & $\% 1$ & $\mathrm{TP}^{2}$ & $\overline{\mathrm{FC}^{3}}$ & $\%^{1}$ & $\mathrm{TP}^{2}$ & $\overline{\mathrm{FC}^{3}}$ & $\% 1$ & $\mathrm{TP}^{2}$ & $\overline{\mathrm{FC}^{3}}$ & $\%^{1}$ & $\mathrm{TP}^{2}$ & $\mathrm{FC}^{3}$ \\
\hline Diaphragm & nd & 575 & - & 1.3 & 32 & - & 14.4 & 4.3 & 11.1 & 25.1 & 0.5 & 19.3 & 32.6 & 0.17 & 25.1 \\
\hline Psoas Major & nd & 750 & - & 2.2 & 35 & - & 15.2 & 3.9 & 6.9 & 18.0 & 0.7 & 8.2 & 51.8 & 0.13 & 23.5 \\
\hline Longissimus Lumborum & nd & 675 & - & 1.6 & 16 & - & 8.6 & 3.2 & 5.4 & 30.2 & 0.4 & 18.9 & 47.2 & 0.11 & 29.5 \\
\hline
\end{tabular}

The peptides detected for the LL and DIA are consistent with the assignment to this F1SDX9 as well. However, the assignment of LL and DIA Prdx2 preparations to Prxd2 Accession Number A0A287AJ76 (a 214 amino acid protein with a predicted molecular mass of 23,360 Da and an isoelectric point of 5.1) could not be ruled out. Nevertheless, based on the behavior of all 3 preparations on anion exchange columns, gel filtration procedures, and SDS-polyacrylamide gels, it is most likely that all 3 preparations are consistent with the Prdx2 Accession Number F1SDX9.

About half of the total peptide spectrum matches (PSM) were assigned to Prdx2. The DIA band had 938 of 2,210 PSM identified as Prdx2 with a sequence coverage of $49 \%$. The PM band had 1,354 of 2,713 PSM identified as Prdx2 with a sequence coverage of $82 \%$. Lastly, the LL band had 1,145 of 2,551 PSM identified as $\operatorname{Prdx} 2$ with a sequence coverage of $51 \%$. About half of the total PSM for the band identification were Prdx2, regardless of muscle tissue. The majority of the remaining PSM were associated with peptidase S1 domain-containing protein (Accession Number: A0A4X1V2S2).

To our knowledge, the method described here is the first to partially purify $\operatorname{Prdx} 2$ from skeletal muscle. The elution profiles were similar among all 3 muscles based on immunoblot and protein concentration comparisons. Purification methods were similar, yet the resulting final purity was slightly different. As mentioned earlier, Prdx2's abundance is greater in more oxidative muscles based on the immunoblot comparison from Figure 1. The final purity could be different due to muscle fiber type and the abundance of proteins specific to oxidative compared with glycolytic fiber type.

Regardless of the differences in final purity, it is clear that Prdx2's purity was greatly enhanced from the sarcoplasmic extract to the final Superose-12 size exclusion column. An approximately 25 -fold increase in $\operatorname{Prdx} 2$ abundance relative to total protein was observed between the pooled elution from the QSepharose column to the final Superose-12 column in the DIA, PM, and LL. Table 2 documents the percentage of the 22-kDa band after each column chromatography step as a ratio to total protein within the lane and the total protein content of each chromatography step. No 22-kDa band was detected in the sarcoplasmic protein extract; thus, the fold increase is more substantial than the calculation based on the product from the Q-Sepharose step. Approximately 450, 700, and $250 \mu \mathrm{g}$ of Prdx 2 were prepared from $20 \mathrm{~g}$ of DIA, PM, and LL, respectively. After the final Superose-12 size exclusion column, about $75 \mu \mathrm{g}$ of $\operatorname{Prdx} 2$ was collected, and the percentage yield from the methods described here was about $15 \%$ to $20 \%$, regardless of muscle tissue. Significant loss of Prdx2 occurred during the final Superose-12 size exclusion column most likely due to dimerization of Prdx2. Future efforts to improve the yield of Prdx2 are necessary; however, the products of the methods described here demonstrate the partial purification of $\operatorname{Prdx} 2$.

\section{Conclusions}

The methodology presented here demonstrates a reliable and repeatable approach for the partial purification of Prdx 2 from porcine skeletal muscle. The final DIA, PM, and LL samples contain approximately $33 \%$, $52 \%$, and $50 \% \operatorname{Prdx} 2$, respectively. Liquid chromatography with tandem mass spectrometry data validate the partial purification of Prdx2. The partial purification of $\operatorname{Prdx} 2$ from skeletal muscle gives a context and chance for less interference from other proteins during in vitro experiments. The changes in oxidation state and abundance of $\operatorname{Prdx} 2$ will be more easily analyzed in 
a partially pure sample compared with a crude protein extract. Reliable access to a partially purified Prdx2 will make it possible to use in vitro methods to determine the significance of changes of $\operatorname{Prdx} 2$ oxidation states and abundance during the perimortem and postmortem period.

\section{Acknowledgments}

This study was supported by a grant from the USDA National Institute for Food and Agriculture (Award Number 2019-67017-29181) and the Iowa Agricultural and Home Economics Experiment Station (Project Number IOW04121).

\section{Literature Cited}

Bayer, S. B. 2015. Redox state of erythrocyte peroxiredoxin 2 during oxidative stress and its effect on membrane binding. Ph.D. diss., University of Otago, Christchurch, NZ. (https:// ourarchive.otago.ac.nz/bitstream/handle/10523/5786/).

Brand, M. D. 2016. Mitochondrial generation of superoxide and hydrogen peroxide as the source of mitochondrial redox signaling. Free Radical Bio. Med. 100:14-31. https://doi.org/10. 1016/j.freeradbiomed.2016.04.001.

Carlson, K. B., K. J. Prusa, C. A. Fedler, E. M. Steadham, E. HuffLonergan, and S. M. Lonergan. 2017. Proteomic features linked to tenderness of aged pork loins. J. Anim. Sci. 95:2533-2546. https://doi.org/10.2527/jas2016.1122.

Estévez, M. 2011. Protein carbonyls in meat systems: A review. Meat Sci. 89:259-279. https://doi.org/10.1016/j.meatsci.2011.04.025.

Glancy, B., and R. S. Balaban. 2011. Protein composition and function of red and white skeletal muscle mitochondria. Am. J. Physiol.-Cell Ph. 300:C1280-C1290.https://doi.org/10.1152/ ajpcell.00496.2010.

Karplus, P. A. 2015. A primer on peroxiredoxin biochemistry. Free Radical Bio. Med. 80:183-190. https://doi.org/10.1016/j. freeradbiomed.2014.10.009.

Kim, Y. H., E. Huff-Lonergan, J. G. Sebranek, and S. M. Lonergan. 2010. High-oxygen modified atmosphere packaging system induces lipid and myoglobin oxidation and protein polymerization. Meat Sci. 85:759-767. https://doi.org/10.1016/j. meatsci.2010.04.001.

Lametsch, R., S. M. Lonergan, and E. Huff-Lonergan. 2008. Disulfide bond within $\mu$-calpain active site inhibits activity and autolysis. BBA-Proteins Proteom. 1784:1215-1221. https://doi.org/10.1016/j.bbapap.2008.04.018.

Lim, Y.-S., M.-K. Cha, C.-H. Yun, H.-K. Kangwha Kim, and I.-H. Kim. 1994. Purification and characterization of thiol-specific antioxidant protein from human red blood cell: A new type of antioxidant protein. Biochem. Bioph. Res. Co. 199:199-206. https://doi.org/10.1006/bbrc.1994.1214.

Lund, M. N., R. Lametsch, M. S. Hviid, O. N. Jensen, and L. H. Skibsted. 2007. High-oxygen packaging atmosphere influences protein oxidation and tenderness of porcine longissimus dorsi during chill storage. Meat Sci. 77:295-303. https://doi.org/10. 1016/j.meatsci.2007.03.016.
Maddock Carlin, K. R. M., E. Huff-Lonergan, L. J. Rowe, and S. M. Lonergan. 2006. Effect of oxidation, $\mathrm{pH}$ and ionic strength on calpastatin inhibition of $\mu$ - and m-calpain. J. Anim. Sci. 84:925-937. https://doi.org/10.2527/2006.844925x.

Matte, A., M. Bertoldi, N. Mohandas, X. An, A. Bugatti, A. M. Brunati, M. Rusnati, E. Tibaldi, A. Siciliano, F. Turrini, S. Perrotta, and L. De Franceschi. 2013. Membrane association of peroxiredoxin- 2 in red cells is mediated by the $\mathrm{N}$-terminal cytoplasmic domain of band 3. Free Radical Bio. Med. 55:2735. https://doi.org/10.1016/j.freeradbiomed.2012.10.543.

Melody, J. L., S. M. Lonergan, L. J. Rowe, T. W. Huiatt, M. S. Mayes, and E. Huff-Lonergan. 2004. Early postmortem biochemical factors influence tenderness and water-holding capacity of three porcine muscles. J. Anim. Sci. 82:11951205. https://doi.org/10.2527/2004.8241195x.

Mitacek, R. M., Y. Ke, J. E. Prenni, R. Jadeja, D. L. VanOverbeke, G. G. Mafi, and R. Ramanathan. 2019. Mitochondrial degeneration, depletion of $\mathrm{NADH}$, and oxidative stress decrease color stability of wet-aged beef longissimus steaks. J. Food Sci. 84:38-50. https://doi.org/10.1111/1750-3841.14396.

Patterson, B. M., A. C. Outhouse, E. T. Helm, L. G. Johnson, E. M. Steadham, J. C. M. Dekkers, K. J. Schwartz, N. K. Gabler, S. M. Lonergan, and E. Huff-Lonergan. 2021. Novel observations of peroxiredoxin-2 profile and protein oxidation in skeletal muscle from pigs of differing residual feed intake and health status. Meat Muscle Biol. https://doi.org/10.22175/ mmb.12241 (in press).

Rhee, S. G., and I. S. Kil. 2017. Multiple functions and regulation of mammalian peroxiredoxins. Annu. Rev. Biochem. 86:749-775. https://doi.org/10.1146/annurev-biochem-060815-014431.

Rhee, S. G., and H. A. Woo. 2011. Multiple functions of peroxiredoxins: Peroxidases, sensors and regulators of the intracellular messenger $\mathrm{H} 2 \mathrm{O} 2$, and protein chaperones. Antioxid. Redox Sign. 15:781-794. https://doi.org/10.1089/ars.2010. 3393.

Rhee, S. G., and H. A. Woo. 2020. Multiple functions of 2-Cys peroxiredoxins, I and II, and their regulations via post-translational modifications. Free Radical Bio. Med. 152:107-115. https://doi.org/10.1016/j.freeradbiomed.2020.02.028.

Rowe, L. J., K. R. Maddock, S. M. Lonergan, and E. HuffLonergan. 2004a. Influence of early postmortem protein oxidation on beef quality. J. Anim. Sci. 82:785-793. https://doi. org/10.2527/2004.823785x.

Rowe, L. J., K. R. Maddock, S. M. Lonergan, and E. Huff-Lonergan. 2004b. Oxidative environments decrease tenderization of beef steaks through inactivation of $\mu$-calpain. J. Anim. Sci. 82:32543266. https://doi.org/10.2527/2004.82113254x.

Schulte, M. D., L. G. Johnson, E. A. Zuber, E. M. Steadham, A. D. King, E. J. Huff-Lonergan, and S. M. Lonergan. 2020. Investigation of the sarcoplasmic proteome contribution to the development of pork loin tenderness. Meat Muscle Biol. 4:1-14. https://doi.org/10.22175/mmb.9566.

Toniolo, L., M. Patruno, L. Maccatrozzo, M. A. Pellegrino, M. Canepari, R. Rossi, G. D’Antona, R. Bottinelli, C. Reggiani, and F. Mascarello. 2004. Fast fibres in a large animal: Fibre types, contractile properties and myosin expression in pig skeletal muscles. J. Exp. Biol. 207:1875-1886. https:// doi.org/10.1242/jeb.00950. 